\title{
Establishment and detailed functional and molecular genetic characterisation of a novel sacral chordoma cell line, MUG-Chor1
}

\author{
BEATE RINNER $^{1}$, ELKE VERENA FROEHLICH ${ }^{2}$, KARIN BUERGER ${ }^{1}$, HEIKE KNAUSZ ${ }^{1}$, \\ BIRGIT LOHBERGER $^{2}$, SUSANNE SCHEIPL ${ }^{2}$, CARINA FISCHER ${ }^{1}$, ANDREAS LEITHNER ${ }^{2}$, \\ CHRISTIAN GUELLY ${ }^{1}$, SLAVE TRAJANOSKI ${ }^{1}$, KAROLY SZUHAI ${ }^{3}$ and BERNADETTE LIEGL ${ }^{4}$ \\ ${ }^{1}$ Center for Medical Research; ${ }^{2}$ Department of Orthopaedic Surgery, Medical University of Graz, \\ Austria; ${ }^{3}$ Department of Molecular Cell Biology, Leiden University Medical Center, Leiden, \\ The Netherlands; ${ }^{4}$ Institute of Pathology, Medical University of Graz, Austria
}

Received July 18, 2011; Accepted August 24, 2011

DOI: 10.3892/ijo.2011.1235

\begin{abstract}
Chordomas are rare, low to intermediate grade malignant bone tumors of the axial skeleton. Current treatment options are limited to surgical procedures, as chordomas are largely resistant to conventional radiation and chemotherapy. Cell lines are valuable tools for exploring molecular mechanisms involved in tumorigenesis and they have a fundamental impact on the development of new anticancer agents. To date, only two chordoma cell lines exist world-wide. In the present study we report a third chordoma cell line, MUG-Chor1, as well as corresponding cultured fibroblasts established from a recurrent morphologically 'classic' sacrococcygeal chordoma of a 58-year-old Caucasian female. The cells are brachyury-positive and have the characteristics of chordoma. The genetic profile of the primary chordoma and the established chordoma cell line was investigated during the culturing period (early and late passage). MUG-Chorl is karyotypically, $<2 n>43-47, X X, \operatorname{del}(3)$ (q1?)[11], +7,del(9)(p1?),der(9;15)(q10;q10),-10,+der(12)t(9;12) (p2?;q1?),der (12)t $(12 ; 19)(\mathrm{p} ; \mathrm{p}) \mathrm{t}(17 ; 19)(\mathrm{q} ; \mathrm{q}),-15, \operatorname{der}(17 ; 21)$ (q10;q10), der(20)t(10;20) (q25?26?;q11?12?),-21,-22[20]/ idemx2[5] and displays known, chordoma-typical genetic changes, such as chromosomal gains at T/brachyury locus (6q27), losses at 9p24.3-p13.1 (includes the CDKN2a/CDKN2b locus), 10p15.3-q23.32 (includes the PTEN locus) and losses of 10q25.2 (includes the PDCD4 locus). MUG-Chor1 bears a
\end{abstract}

Correspondence to: Dr Bernadette Liegl, Institute of Pathology, Medical University of Graz, Auenbruggerplatz 25, 8036 Graz, Austria

E-mail: bernadette.liegl-atzwanger@medunigraz.at

Dr Beate Rinner, Medical University of Graz, Center for Medical Research, Stiftingtalstrasse 24, 8010 Graz, Austria

E-mail: beate.rinner@medunigraz.at

Key words: chordoma, cell line, brachyury, matrix metalloproteinases marked resemblance to chordomas in vivo and is, therefore, an optimal in vitro chordoma model.

\section{Introduction}

Chordomas are rare, malignant, locally destructive growing tumors accounting for approximately 1-4\% of all primary malignant bone tumors (1). The majority of cases are distributed along the axial spine, usually in the sacrococcygeal region. Chordomas are, to a great extent, resistant to conventional chemo- and radiotherapy, therefore surgery remains the main treatment option (1-5). Based on the anatomic location and large tumor size, a wide curative excision is rarely feasible. Hence, incidence of disease recurrence is common and metastases have been reported in up to $40 \%$ of cases (5-8).

Histologically, chordomas with 'classic' morphology are characterised by a lobulated growth pattern. The individual nodules are separated by fibrous bands and the tumor cells are set in a myxoid background. The tumor cells are arranged in sheets, cords or single cells, and frequently reveal a multivacuolated cytoplasm, known as 'physaliphorous cells'. Immunohistochemically, the tumor cells co-express Pan-Cytokeratin (Pan-CK), CK8, CK19, EMA, S100 and vimentin (9-11). Brachyury (also known as T; MIM, 601397), a nuclear transcription factor with a key role in the formation of the posterior mesoderm and axial development (12), was recently presented as a specific and sensitive marker for chordomas $(7,8,13)$. The use of brachyury in the diagnostic setting has been further demonstrated by using brachyury expression as a specific marker to distinguish chordoma from soft tissue myoepithelioma and to differentiate chordomas from cartilaginous mimics $(7,8)$.

Despite recent scientific advances $(8,14-19)$, the molecular and genetic processes involved in the development and progression of chordomas have yet to be fully elucidated and new treatment options are still lacking. To gain further insight into the pathogenesis of this rare tumor entity, and to explore new treatment options, in vitro models (e.g., cell lines) that act 
like chordomas in vivo are urgently required. In the present study we report a new well-characterized chordoma cell line, the third chordoma cell line world-wide $(20,21)$.

\section{Materials and methods}

Case report. A 54-year-old Caucasian woman presented at the Department of Orthopedic Surgery, Medical University of Graz, Austria, in 2006, with a 15-month history of increasing sacral pain, incipient aconuresis and peripheral neuropathy of both lower extremities. Plain radiography and magnetic resonance imaging (MRI) revealed a $10.6 \times 7.6 \times 10 \mathrm{~cm}$ mass in the caudal area of the sacrum and the whole tailbone infiltrating the neuroforamina and nerve roots S2-S5, as well as the rectal wall. An incision biopsy was performed. Histological evaluation revealed a multilobulated tumor (Fig. 1A) composed of cords and nests of tumor cells with a pale to eosinophilic, partly vacuolated, cytoplasm (Fig. 1B). The tumor cells showed a co-expression of Pan-CK, CK8, CK19, EMA, focal S-100, vimentin and brachyury. The histological diagnosis showed a 'classic' case of chordoma. During the surgical procedure, fresh chordoma tissue was obtained and placed directly in the cell culture medium. The patient is currenlty living with the disease, 45 months following initial diagnosis.

Cell culture. The tumor tissue was obtained immediately after surgery. Following mechanical disaggregation of the tumor tissue into approximately $1-2 \mathrm{~mm}^{3}$ pieces, the mixture of cultures was carried out in fractions. Fraction I contained mechanically dissociated tumor cells after vortexing. Fraction II comprised a cell fraction after the tumor pieces were treated with $200 \mu \mathrm{l}$ collagenase for $30 \mathrm{~min}$ at $37^{\circ} \mathrm{C}$, and fraction III included only the tumor pieces. All fractions were cultured in Iscove/RPMI 4:1 (PAA Laboratory, Pasching, Austria) containing 10\% fetal bovine serum (FBS; PAA Laboratory), $1 \%$ insulin, transferrin, sodium selenite (ITS; PAA Laboratory), $2 \mathrm{mM}$ glutamine and $1 \%$ penicillin/ streptomycin (Pen/Strep; PAA Laboratory). Incubation was carried out at $37^{\circ} \mathrm{C}$ in a humidified atmosphere of $5 \% \mathrm{CO}_{2}$. In addition, several different oxygen conditions, ranging from normal ( $21 \%$ oxygen) to hypoxic ( $1 \%$ oxygen), were tested. The chordoma cells grow at a $\mathrm{pH}$ of 7.4.

Selection of tumor cells. The tumor cells were separated from fibroblasts by selective adhesion and selective detachment techniques $(22,23)$. The separated fibroblasts were cultured and used as the negative control for the matrix metalloproteinase (MMP) detection.

Optimization of growth conditions. Following a culture period of 4 months and a passage number of 5, cells underwent a crisis. We increased the FBS concentration from 10 to $20 \%$, and the ITS concentration from 1 to 5\%. After applying these conditions for 1 week, the initial medium was used again. Since that crisis, the cells grew consistently and showed a doubling time of approximately 7-10 days. Culture medium was changed twice a week and splitting of the cell culture was performed every 10 days at a confluence of $70-80 \%$. All cell cultures were periodically checked for mycoplasma by PCR.
Growth kinetics. To assess cell proliferation, CellTiter $96^{\circledR}$ aqueous non-radioactive cell proliferation assay (MTS; Promega, Mannheim, Germany) was employed, according to the manufacturer's instructions. Chrodoma cells $\left(1 \times 10^{3}\right)$ were seeded and MTS solution was added to each well, with an incubation period of 21 days.

Immunohistochemistry (IHC). Immunohistochemical studies using the streptavidin-biotin peroxidase complex method were carried out employing antibodies against the following: Pan-CK, CK8, CK19, EMA, S-100 protein, vimentin and brachyury. Appropriate positive and negative controls are included.

Western blot analysis. For total protein analysis, the cells were resuspended in lysis buffer $(50 \mathrm{mM}$ Tris- $\mathrm{HCl} \mathrm{pH} \mathrm{7.4,} 150 \mathrm{mM}$ $\mathrm{NaCl}, 50 \mathrm{mM}$ NaF, $1 \mathrm{mM}$ EDTA, 10\% NP-40, 1\% Triton-X and protease inhibitors), incubated on ice for $10 \mathrm{~min}$ and then centrifuged at $15,000 \mathrm{rpm}$ for $15 \mathrm{~min}$. Aliquots of protein extracts $(20 \mu \mathrm{g})$ were separated on 12\% SDS-PAGE and electroblotted onto $0.45 \mu \mathrm{m}$ Hybond ECL nitrocellulose membrane (Amersham Biosciences, Little Chalfont, UK). We used mouse monoclonal brachyury (ab57480; Abcam, Cambridge, UK) and mouse monoclonal anti-actin (A4700; Sigma Aldrich, Vienna, Austria) as the primary antibodies. The blots were developed using horseradish peroxidise-conjugated secondary antibody (Dako, Vienna, Austria) at room temperature for $1 \mathrm{~h}$ and the SuperSignal ${ }^{\circledR}$ West Pico Chemiluminescent substrate (Thermo Scientific, Rockford, IL), according to the manufacturer's instructions.

Cytogenetics. Cells were harvested using the chemically induced chromosome condensation technique (24). Briefly, at the moment of harvesting, RPMI-1640 medium was replaced by serum-free F10 medium and $25 \mathrm{mmol} / \mathrm{l} \mathrm{HEPES}, \mathrm{pH} 7.4$ (Gibco, Invitrogen), followed by two washes. The medium was then replaced by a solution of $80 \mathrm{nmol} / \mathrm{l}$ CalyculinA (Biomol Research Laboratories, Plymouth Meeting, PA) in the F10 medium. Cells were monitored for morphological changes using an inverted-phase contrast microscope to detect a cytoplasmic 'budding' pattern, and after $20 \mathrm{~min}$ of incubation at $37^{\circ} \mathrm{C}$, cells were washed twice with a $37^{\circ} \mathrm{C}$ phosphate-buffered solution and collected in $15 \mathrm{ml}$ tubes. The cell suspension was then incubated with hypotonic solution $0.075 \mathrm{~mol} / 1 \mathrm{KCl}$ at $37^{\circ} \mathrm{C}$ for $8 \mathrm{~min}$, followed by centrifugation at $700 \mathrm{rpm}$ for $6 \mathrm{~min}$. Following the removal of all, aside from $1.5 \mathrm{ml}$, of the supernatant, the cell pellets were resuspended and fixed with three changed washes of methanol/glacial acetic acid (4:1) solution. Cell suspensions were then dropped onto clean glass slides (Gold Seal, Portsmouth, NH, USA) and dried for $24-48 \mathrm{~h}$ at room temperature before hybridizations. For long-term storage, slides were kept in sealed plastic bags at $-20^{\circ} \mathrm{C}$.

Combined binary ratio fluorescence in situ hybridization (COBRA-FISH). Slides with metaphase chromosomes were hybridized using a multicolor FISH approach, known as COBRA-FISH. The 43-color FISH staining of every chromosome arm in a different color combination, digital imaging and analysis were performed as previously described (25). 
Table I. Summary of key CNV/LOH data derived from Affymetrix 6.0 SNP microarrays

\begin{tabular}{|c|c|c|c|c|c|c|}
\hline & $\begin{array}{c}\mathrm{CN} \\
\text { state }\end{array}$ & Type & $\begin{array}{l}\text { Cytoband } \\
\text { start }\end{array}$ & $\begin{array}{c}\text { Cytoband } \\
\text { end }\end{array}$ & $\begin{array}{l}\text { Number } \\
\text { of genes }\end{array}$ & Cancer associated genes \\
\hline $\mathrm{Tu}$ & 3 & Gain & $2 q 35$ & $2 q 35$ & & \\
\hline p5 & 3 & Gain & $2 q 35$ & $2 q 35$ & 17 & IGFBP2; IGFBP5 \\
\hline p13 & 3 & Gain & $2 q 35$ & $2 q 35$ & & \\
\hline $\mathrm{Tu}$ & 1 & Loss & $6 \mathrm{p} 22.1$ & $6 \mathrm{p} 21.32$ & & \\
\hline p5 & 1 & Loss & $6 \mathrm{p} 22.3$ & $6 \mathrm{p} 21.31$ & 303 & HIST1H1B \\
\hline p13 & 1 & Loss & 6922.3 & 6921.31 & & \\
\hline $\mathrm{Tu}$ & 3 & Gain & $6 q 27$ & $6 q 27$ & & \\
\hline p5 & 4 & Gain & $6 q 27$ & $6 q 27$ & 1 & Brachyury/T \\
\hline p13 & 4 & Gain & $6 q 27$ & $6 q 27$ & & \\
\hline $\mathrm{Tu}$ & 3 & Gain & $7 \mathrm{p} 22.3$ & $7 q 36.3$ & & CARD11,PMS2, ETV1, JAZF1, RALA, IKZF1, \\
\hline p5 & 3 & Gain & $7 \mathrm{p} 22.3$ & $7 q 36.3$ & 1055 & EGFR, SBDS, CDK6, MET, SMO, KIAA1549, \\
\hline p13 & 3 & Gain & $7 \mathrm{p} 22.3$ & $7 q 36.3$ & & BRAF \\
\hline $\mathrm{Tu}$ & 1 & Loss & 9 p22.1 & $9 \mathrm{p} 13.2$ & 8 & CDKN2A, CDKN2B, FANCG \\
\hline p5 & 0 & Loss & $9 \mathrm{p} 21.3$ & $9 \mathrm{p} 21.2$ & & \\
\hline p13 & 0 & Loss & $9 \mathrm{p} 21.3$ & $9 \mathrm{p} 21.2$ & & \\
\hline $\mathrm{Tu}$ & 1 & Loss & $10 \mathrm{q} 25.2$ & $10 \mathrm{q} 25.2$ & & \\
\hline p5 & 0 & Loss & $10 \mathrm{q} 25.2$ & $10 \mathrm{q} 25.2$ & 6 & PDCD4 \\
\hline p13 & 0 & Loss & $10 \mathrm{q} 25.2$ & $10 \mathrm{q} 25.2$ & & \\
\hline $\mathrm{Tu}$ & 3 & Gain & $12 \mathrm{p} 11.22$ & $12 q 24.33$ & & KRAS, ATF1, ERBB3, CDK4, MDM2, BTG1, \\
\hline p5 & 3 & Gain & $12 \mathrm{p} 12.1$ & $12 q 24.33$ & 811 & PTPN1, HNF1A \\
\hline p13 & 3 & Gain & $12 \mathrm{p} 12.1$ & $12 q 24.33$ & & \\
\hline $\mathrm{Tu}$ & 3 & Gain & $17 \mathrm{q} 21.33$ & $17 q 22$ & & \\
\hline $\mathrm{Tu}$ & 3 & Gain & $17 q 25.3$ & $17 q 25.3$ & 447 & BRIP1, PRKAR1A, KIAA1618, ASPSCR1 \\
\hline p5 & 3 & Gain & $17 q 21.32$ & $17 q 25.3$ & & \\
\hline p13 & 3 & Gain & $17 \mathrm{q} 21.32$ & $17 q 25.3$ & & \\
\hline $\mathrm{Tu}$ & 3 & Gain & $19 q 13.31$ & $19 q 13.31$ & & \\
\hline p5 & 3 & Gain & $19 q 12$ & $19 q 13.32$ & 360 & CEBPA, AKT2, ERCC2 \\
\hline p13 & 3 & Gain & $19 q 112$ & $19 q 13.32$ & & \\
\hline
\end{tabular}

Hybridizations with individual libraries labeled with single fluorochromes were used to confirm the detected rearrangements. Chromosomal breakpoints were assigned using inverted images counterstained with 4',6-diamidino-2-phenylindole (DAPI; Downers Grove, IL) together with the information derived from the short- and long-arm specific hybridization during COBRA-FISH. Karyotypes were described according to ISCN 2009.

Affymetrix SNP 6.0 array processing and analysis. Affymetrix GeneChip Human Mapping SNP 6.0 arrays were performed as described in the Genome-Wide Human SNP Nsp/Sty 6.0 User Guide (Affymetrix Inc., Santa Clara, CA, USA).

SNP 6.0 data were imported and normalized using the Genotyping Console 4.0 program default settings. All samples passing QC criteria were subsequently genotyped using the Birdseed (v2) algorithm. We used 60 raw HapMap data generated with the Affymetrix Genome-Wide Human SNP Array 6.0 as a reference. Data were obtained from the
Affymetrix web site and used for normalization. For visualization of copy number state and loss of heterozygosity (LOH), Chromosome Analysis Suite 1.1 software was used.

Cell line identification Power Plex 16 system. Frozen tumor tissue was dissected into small pieces and resuspended in $180 \mu 1$ ATL buffer from Qiagen (Vienna, Austria). The cell pellet $\left(3.5 \times 10^{5}\right)$ from MUG-Chor1 (p20) was resuspended in $200 \mu \mathrm{l} \mathrm{PBS}$, and $20 \mu \mathrm{l}$ proteinase $\mathrm{K}$ and $200 \mu \mathrm{l}$ AL buffer from Qiagen were then added. DNA preparations were carried out using the QIAamp DNA Mini kit (Qiagen) according to the manufacturer's instructions, . After normalizing the DNA, $1 \mu \mathrm{l}$ of sample was amplified using Power Plex 16 System (Promega, Vienna, Austria) in a $10 \mu \mathrm{l}$ reaction. The product (1 $\mu \mathrm{l}$ ) was mixed with Hi-Di formamide (Applied Biosystems Inc., Foster City, CA) and Internal Lane Standard (ILS600), denatured and fractionated on an ABI 3730 genetic analyzer. Resulting data were processed and evaluated using ABI Genemapper 4.0. 


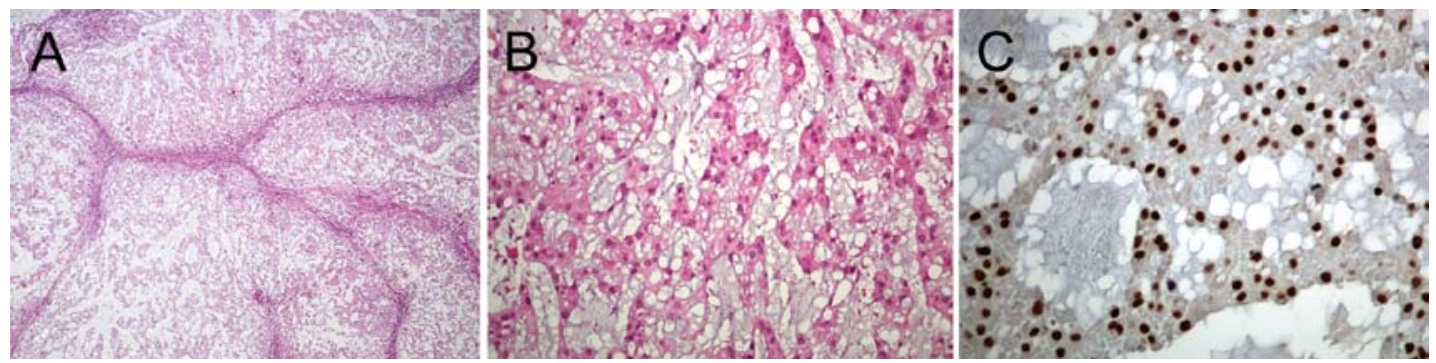

Figure 1. Histology and IHC of the primary tumor ('classic' chordoma) used for the establishment of the MUG-Chorl. (A) Low power magnification, x4, of a 'classic' chordoma with the typical lobulated appearance. (B) Higher power magnification, x10, of a 'classic' chordoma showing a prominent myxoid matrix and embedded cords and strands of tumor cells with eosinophilic cytoplasm as well as vacuolated tumor cells, known as physaliphorous cells. (C) Specific nuclear immunohistochemical expression of brachyury in the parental 'classic' chordoma.
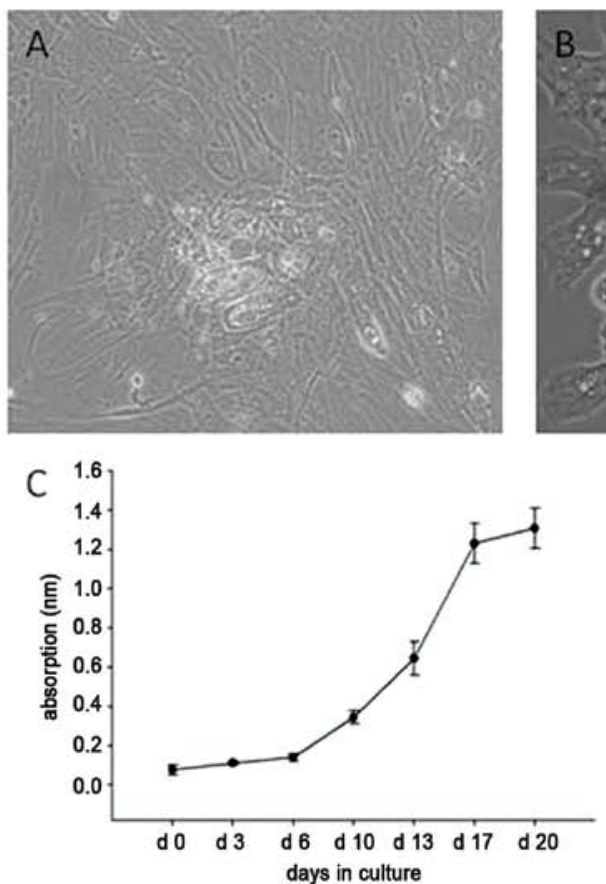

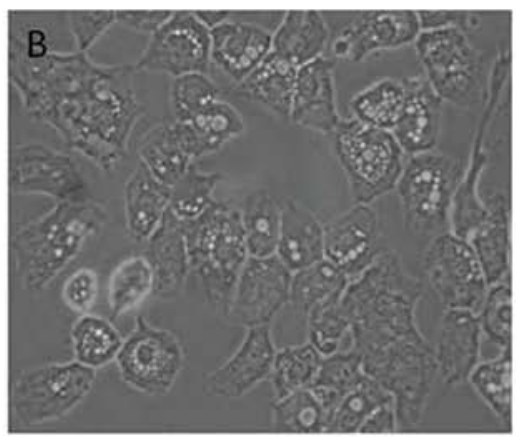

D

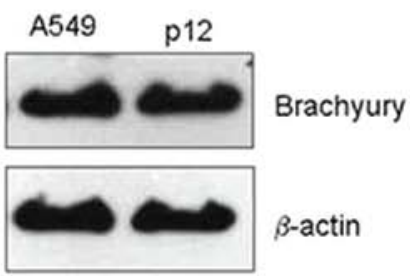

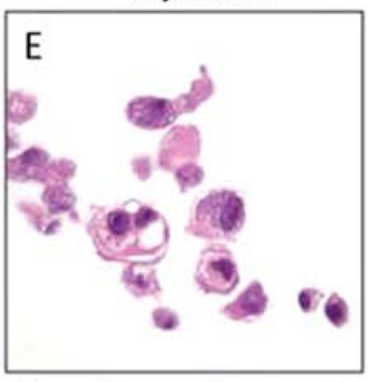

$\mathrm{F}$
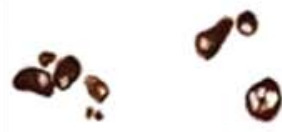

8
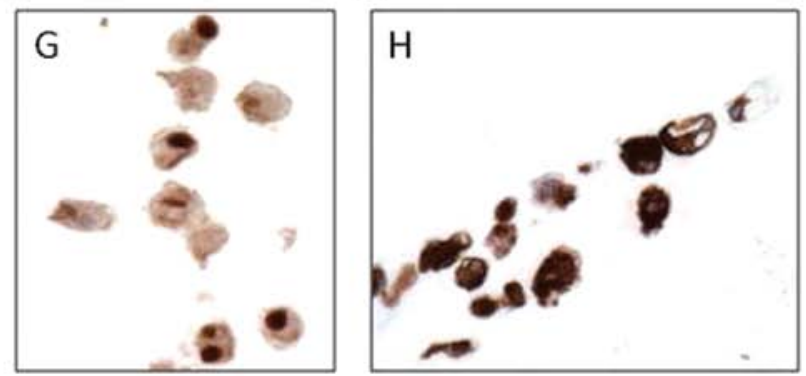

Figure 2. Morphological features of the MUG-Chorl cell line. (A) Morphology of MUG-Chor1 at lower passage, showed mostly fibroblasts and some tumor cells with a vacuolated cytoplasm. (B) Morphology of MUG-Chorl at higher passage, typical physaliphorous appearance of chordoma cells (magnification, x200), Olympus. (C) Growth curve of MUG-Chor1. (D) Western blot analysis of MUG-Chor1. During long-term cultivation, Western blot analysis confirmed strong positivity for brachyury. $\beta$-actin was used as the internal loading control and A549 as the positive control. (E) Hematoxylin and eosin staining of cultured chordoma cells (cell block) showing eosinophilic partly vacuolated cytoplasm. (F) Cultured chordoma cells showing strong cytokeratin expression by IHC. (G) Cultured chordoma cells showing a specific nuclear brachyury expression by IHC. (H) Cultured chordoma cells showing strong vimentin expression by IHC. 
Human MMP Fluorokine ${ }^{\circledR}$ MAP (MMP-1, MMP-2, MMP-3 and MMP-9). MUG-Chor1 cells $(100,000)$ of early passage (p5), following several months of cultivation (p20), were seeded in 6-well plates. The cells were trypsinized and counted. Cell culture supernatants were 5-fold diluted with calibrator diluent. Human MMP Fluorokine ${ }^{\circledR}$ MAP assay (R\&D Systems, Wiesbaden, Germany) was performed in duplicates, according to the manufacturer's instructions. All subsequent steps were carried out using the same procedure. The microparticles were resuspended in $100 \mu 1$ washing buffer and detected by suspension array system (BioRad BioPlex ${ }^{\mathrm{TM}}$ dual laser, CA, USA).

Real-time RT-PCR. Real-time RT-PCR was performed to determine the relative expression of the MMP-1, $-2,-3$, and -9 genes. Total RNA was isolated from the treated and untreated cells using the RNeasy mini kit (Qiagen, Hilden, Germany), according to the manufacturer's instructions. DNA was digested with $1 \mathrm{U}$ DNase (Fermentas, St. Leon-Rot, Germany) per $\mu \mathrm{g}$ RNA. RNA (1 $\mu \mathrm{g})$ was reverse-transcribed using the RevertAid cDNA Synthesis Kit (Fermentas). Realtime PCR reactions were performed in triplicates using the Platinum SYBR-Green Super Mix with ROX (Invitrogen) on AB7900HT (Applied Biosystems, Invitrogen). Due to their stable expression in different tissues, the housekeeping genes glyceraldehyde 3-phosphate dehydrogenase (GAPDH), $\beta$-actin (ACTB) and hypoxanthine phosphoribosyltransferase (hprt-n) served as the internal control. The following primers were used: GAPDH fw, 5' AAGGTCGGAGTCAACGGA 3' and rev, 5' ACCAGAGTTAAAAGCAGCCCT 3'; hprt-n-fw, 5' ATGGGAGGCCATCACATT 3' and rev, 5' ATGTAATCC AGCAGGTCAGCAA 3'; ACTB fw, 5' CTGGAACGGTG AAGGTGACA 3' and rev, 5' AAGGGACTTCCTGTAACAA TGCA 3'; MMP-1 fw, 5' CTGTTCAGGGACAGAATGTG CT $3^{\prime}$ and rev, 5' TCGATATGCTTCACAGTTCTAGGG 3'; MMP-2 fw, 5' TGATCTTGACCAGAATACCATCGA $3^{\prime}$ and rev, 5' GGCTTGCGAGGGAAGAAGTT 3'; MMP-3 fw, 5' TTTTGGCCATCTCTTCCTTCA 3' and rev, 5' TGTGGA TGCCTCTTGGGTATC 3'; MMP-9 fw, 5' GGGACGCAG ACATCGTCATC 3' and MMP-9 rev, 5' TCGTCATCGTCGA AATGGGC 3'. The expression levels were calculated based on the $2^{-\Delta \Delta C T}$ method.

\section{Results}

The cultured cells grow as a monolayer with a doubling time of 7-10 days (Fig. 2C). The cell line was maintained in culture for at least 18 months with 45 passages (Fig. 2A and B). The best results were achieved with fraction I cultured in Iscove/ RPMI 4:1, supplemented with $1 \%$ ITS and $10 \%$ FBS in a humidified atmosphere of $5 \% \mathrm{CO}_{2}$ at $37^{\circ} \mathrm{C}$. MuG-Chorl cells grow without coating. In addition, different oxygen conditions, from normal ( $21 \%$ oxygen) to low ( $1 \%$ oxygen), were tested. Cells cultured under low oxygen grew significantly slower than those under normoxic conditions.

MUG-Chor1 cells showed a typical physaliphorous appearance (vacuolated cytoplasm; Fig. 2B and E) and the immunhistochemical profile was identical to that of the parental tumor. The expression of Pan-CK (Fig. 2F), CK8, CK19, brachyury (Fig. 2G), S-100 and vimentin (Fig. 2H) were demonstrated by IHC.
Western blot analysis of the MUG-Chorl cell line was carried out at higher passage for brachyury expression. Immunoblotting confirmed strong positivity for brachyury antibody staining. The brachyury-positive lung carcinoma cell line A-549 served as the control and $\beta$-actin was used as the loading control (Fig. 2D).

COBRA-FISH. At early passage (5) molecular karyotyping of the sample was carried out using a multicolor-FISH technique, known as COBRA-FISH. At the initial stage of culture, out of 11 metaphases, 5 were of tumor origin. The resulting karyotype was $<2 \mathrm{n}>45-47, \mathrm{XX},-3,+7, \operatorname{der}(9 ; 15)(\mathrm{q} 10 ; \mathrm{q} 10),-10, \operatorname{der}(12) \mathrm{t}(9 ; 12)$ $(\mathrm{p} ; \mathrm{q}), \operatorname{der}(12) \mathrm{t}(10 ; 12)(\mathrm{q} ; \mathrm{p}), \operatorname{der}(12) \mathrm{t}(12 ; 19)(\mathrm{p} ; \mathrm{q}) \mathrm{t}(17 ; 19)(\mathrm{q} ; \mathrm{q}), \operatorname{der}(17 ; 21)$ $(\mathrm{q} 10 ; \mathrm{q} 10)$,der(20)t(1;20)(q;q)[5]/46,XX[6]. Following 10 months of cultivation at late passage of the chordoma cells, 25 tumor cells were analyzed. Out of the 25 cells analyzed, 5 had a $4 \mathrm{n}$ content and 20 had a peridiploid chromosome content. The resulting karyotype was: $<2 \mathrm{n}>43-47, \mathrm{XX}, \operatorname{del}(3)(\mathrm{q} 1 ?)[11],+7$, del (9)(p1?),der(9;15)(q10;q10),-10,+der(12)t(9;12)(p2?;q1?),der(12) $\mathrm{t}(12 ; 19)(\mathrm{p} ; \mathrm{p}) \mathrm{t}(17 ; 19)(\mathrm{q} ; \mathrm{q}),-15, \operatorname{der}(17 ; 21)(\mathrm{q} 10 ; \mathrm{q} 10), \operatorname{der}(20) \mathrm{t}(10 ; 20)$ (q25?26?;q11?12?),-21,-22[20]/idemx2[5]. A very stable karyotype was seen in the main line, and in 11 metaphases an additional deletion of the long arm of chromosome 3 was seen (Fig. 3A and B).

Copy number variations $(C N V)$ and $\mathrm{LOH}$. CNV and $\mathrm{LOH}$ were evaluated using Affymetrix 6.0SNP Arrays. DNA isolated from the mononuclear cells (MNCs) of the patients was used as the control. The primary tumor displays $\mathrm{CN}$ gains on chromosomes 1q21-43, 2q35, 5p15.33 6q27 (includes the T/brachyury locus; CN state 3), 7p22.3-q36.3, 9p12-11.1, 12p11.22-q24.33, 17q21.33-q22, 17q25.3, 19q13.31, 22q11.22 and $\mathrm{CN}$ losses on chromosomes 3p24.3-q29, 6p22.121.32, 9p24.1, 9p22.1-p13.2 (includes the p16-CDKN2a/ p15-CDKN2b locus; CN state 1), 10p12.2-11.22, 10q21.2-23.33, $10 \mathrm{q} 24.32,10 \mathrm{q} 25.2,17 \mathrm{p} 13.3,22 \mathrm{q} 11.1-11.21,22 \mathrm{q} 12.1-12.2$, and 22q13.1-13.2. The non-continuous CNV or LOH patterns (e.g., gain at 1q, 12q or loss at 3) very likely result from normal cell contamination (approximately $20 \%$ of the cells are nonneoplastic, as confirmed by immunocytochemical analyses) and/or genetic heterogeneity of another tumor cell clone. The cell line at early passage displays chromosomal gains at 2q34-35, 5q12.3-13.2, 6q27 (includes the T/brachyury locus; CN state of 4), 7p22.3-q36.3, 11q13.2, 12p13.1-12.3, 12p21.1$\mathrm{q} 24.33,17 \mathrm{p} 13.1,17 \mathrm{q} 21.32-\mathrm{q} 25.3,19 \mathrm{q} 12-\mathrm{q} 13.11,19 \mathrm{q} 13.12-13.32$ $19 \mathrm{q} 13.43,20 \mathrm{q} 13.2$ and losses at $6 \mathrm{p} 22.3-\mathrm{p} 21.31,10 \mathrm{p} 15.3-$ $\mathrm{q} 23.32,10 \mathrm{q} 25.2,17 \mathrm{p} 13.3,17 \mathrm{p} 12,22 \mathrm{q} 11.1-13.33, \mathrm{Xp} 11.23$ and Xq21.31 a homozygous loss was seen at 9p24.3-p13.1 (includes the CDKN2a/CDKN2b locus; CN state 0). It is evident from $\mathrm{CNV}$ and $\mathrm{LOH}$ kinetics that during in vitro cultivation, the initially heterogeneous cell population, comprising genetically diverse cell populations, becomes more homogeneous, thus indicating a clonal selection of a subpopulation with a defined genetic profile. The cell line at late passage displays an almost uniform (clonal) $\mathrm{CNV} / \mathrm{LOH}$ pattern harbouring chromosomal alterations similar to early passage. Major chromosomal differences of the cell line vs. the tumor are a normal status of the cell lines for chromosomes 1 and 3 and the copy-neutral LOHs at 10p13.1-q26.3 (both passages) and 12p13.33-p12.1 (early passage; Fig. 4; Tables I and II). 


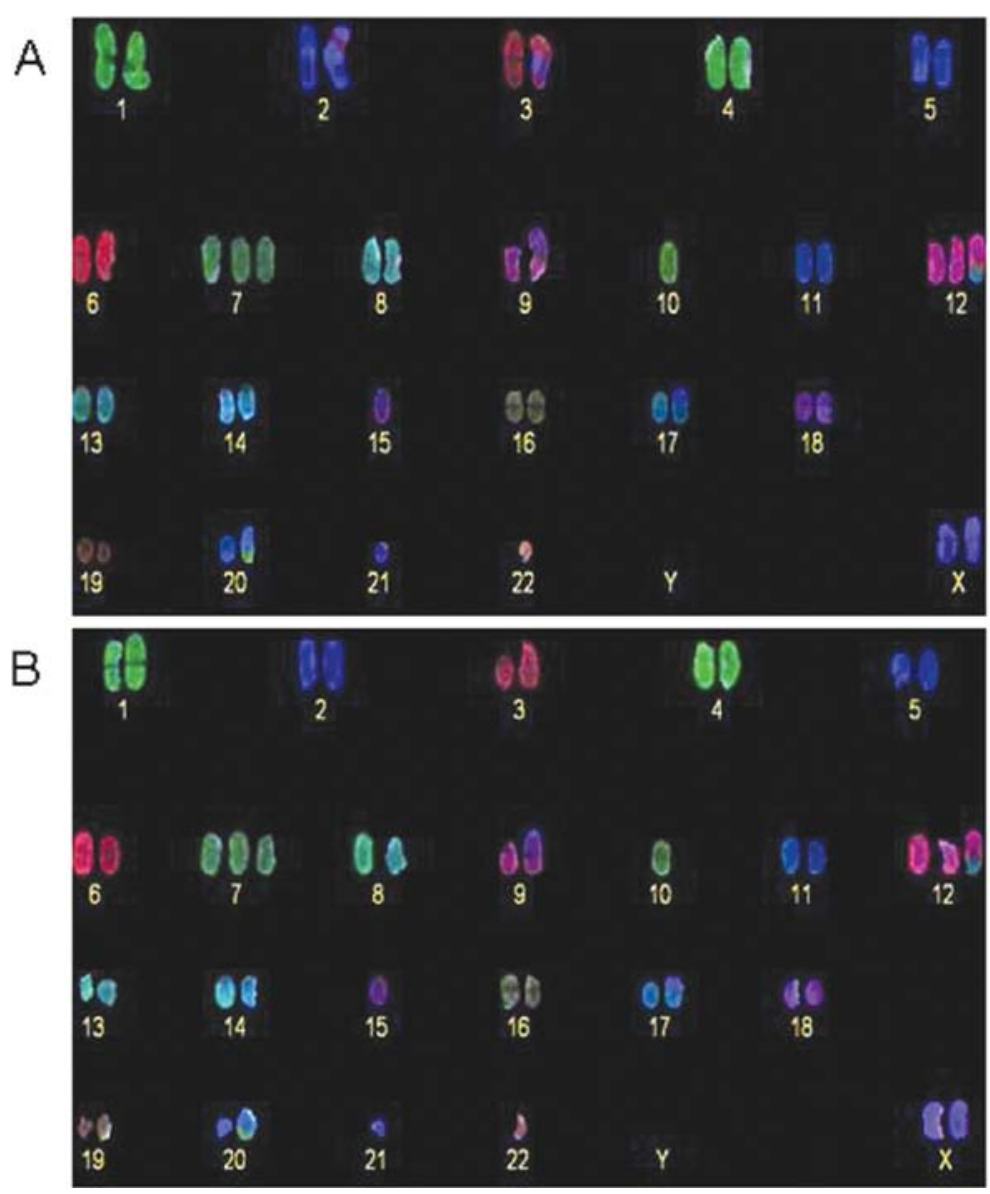

Figure 3. (A) Representative karyotype of MUG-Chorl at late passage: $<2 \mathrm{n}>43-47, \mathrm{XX}, \operatorname{del}(3)(\mathrm{q} 1 ?)[11],+7, \operatorname{del}(9)(\mathrm{p} 1 ?), \operatorname{der}(9 ; 15)(\mathrm{q} 10 ; \mathrm{q} 10), 10,+\operatorname{der}(12) \mathrm{t}(9 ; 12)$ (p2?;q1?),der(12)t(12;19)(p;p)t(17;19)(q;q),-15,der(17;21)(q10;q10),der(20)t(10;20)(q25?26?;q11?12?),-21,-22[20]/idemx2[5] with a 3q deletion. (B) Representative karyotype of MUG-Chorl at late passage without a 3q deletion.

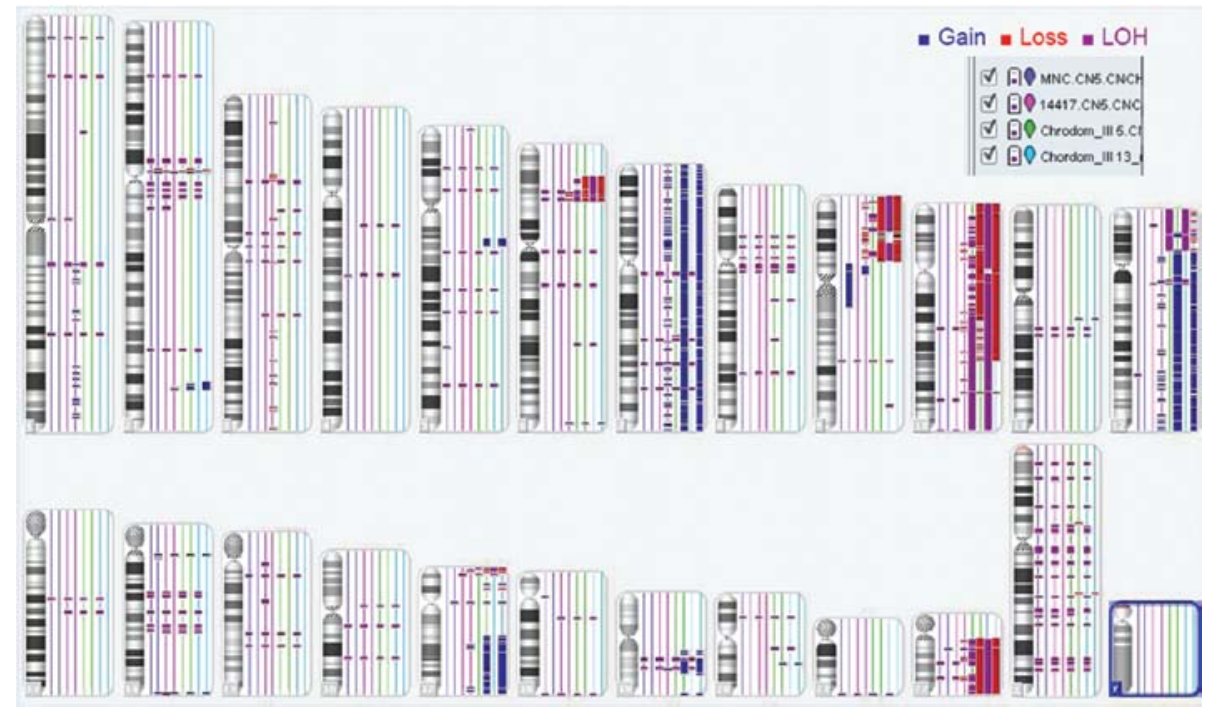

Figure 4. Summary of chromosomal CNVs and LOHs observed for the MNCs of the patients, the primary tumor, as well as early passage and passage 13 of the MUG-Chorl cell line.

Cell line identification. The frozen primary parental tumor tissue and the cell line showed the same short tandem repeat (STR) profile at the markers D3S1358, TH01, D21S11,
D18S51, Penta E, D5S818, D13S317, D7S820, D16S539, CSF1PO, Penta D, Amelogenin, D8S1179, TPOX and FGY. The cell line showed a loss only at vWa allele 17 . With the 
Table II. STR genotype of primary tumor and the MUG-Chor1 cell line.

\begin{tabular}{lcc}
\hline Marker & Primary tumor & MUG-Chor1 \\
\hline D3S1358 & $14 / 17$ & $14 / 17$ \\
THO1 & 9.3 & 9.3 \\
D21S11 & $29 / 33.2$ & $29 / 33.2$ \\
D18S51 & $17 / 23$ & $17 / 23$ \\
Penta E & $5 / 12$ & $5 / 12$ \\
D5S818 & $11 / 12$ & $11 / 12$ \\
D13S317 & 11 & 11 \\
D7S820 & $8 / 11$ & $8 / 11$ \\
D16S539 & $11 / 14$ & $11 / 14$ \\
CSF1P0 & 11 & 11 \\
Penta D & 13 & 13 \\
Amelogenin & $\mathrm{X}$ & $\mathrm{X}$ \\
vWA & $15 / 17$ & 15 \\
D8S1179 & $11 / 12$ & $11 / 12$ \\
TPOX & 8 & 8 \\
FGA & $21 / 26$ & $21 / 26$ \\
\hline
\end{tabular}

help of the STR analysis, it could be clearly demonstrated that the MUG-Chor1 emanated from the parental tumor tissue (Table II).

MMP expression. To examine the MMP expression during the cultivation of the cell line, low and high passages were compared for MMP-1, MMP-2, MMP-3 and MMP-9 by the x-Map technology and by RT-PCR. Low passage of chordoma cells showed high MMP-1, -2 and -3 expressions, compared to the other MMPs (lower MMP-9 expression). As shown in Table III, the expression of MMP-1, -2 and -3 significantly decreased after prolonged culturing. Furthermore, the mRNA levels were determined by RT-PCR. The expression levels were normalized $(\Delta \mathrm{Ct})$ to the expression of mRNA for $\beta$-actin, GAPDH and hprt-n as the internal control and compared to the corresponding $\Delta \mathrm{Ct}(\Delta \Delta \mathrm{Ct})$ in the controls. The mRNA levels of MMP-1 and MMP-2 were significantly decreased compared to lower passage. MMP-3 and MMP-9 mRNA levels were too low to detect (Table III).

\section{Discussion}

Cell lines play a significant role in enhancing our understanding of the molecular mechanisms of diseases and serve as an important in vitro model when searching for novel treatments. Only two chordoma cell lines (U-CH1and U-CH2) exist world-wide and they are difficult to maintain in longterm cultures $(20,21)$. It is therefore necessary to develop well characterized chordoma cell lines.

The developed MUG-Chorl cell line can be maintained in long-term cultures. It also has an almost uniform (clonal) CNV/LOH pattern, which resembles 'classic' chordomas morphologically, by showing multivacuolated (physaliphorous) cells in culture, and, immunohistochemically, by expressing brachyury, Pan-CK, CK8, CK19, S-100, EMA and vimentin. In addition, this cell line harbours genetic alterations consistent with alterations previously reported (21,26-30).

The literature currently available on chordomas reports a near-diploid or moderately hypodiploid karyotype, with several numerical and structural rearrangements. The reported recurrent chromosomal aberrations in chordomas, identified using different techniques, include loss of the entire or parts of chromosomes 3, 4, 10, 13 and 18; loss or rearrangement of $1 \mathrm{p}$ and 9p; and gain of chromosome 7 (21,26-29,31,32). However, consistent structural chromosome aberrations have yet to be reported.

Consistent chromosomal gains observed during in vitro cultivation of MUG-Chor1 include 2q34-q35, 6q27, 7p22.3$\mathrm{q} 36.3,12 \mathrm{p} 12.1-\mathrm{q} 24.33,17 \mathrm{q} 21.32-\mathrm{q} 25.3$ and $19 \mathrm{q} 12-\mathrm{q} 13.32$. MUG-Chorl showed chromosomal gains at the $6 \mathrm{q} 27$ region in the tumor (CN state 3 ) and a further amplification of this locus during cell cultivation (CN state 4$)$. This specific locus maps to brachyury ( $T$ gene), a nuclear transcription factor with a key role in the formation of the posterior mesoderm and axial development (12). Previous studies have demonstrated a consistent, strong brachyury expression in chordomas and gains in the copy number of $T$ in a subset of chordoma cells $(8,14,15)$. Given the close association between familial predisposition to chordoma and germline $T$ duplication, there is convincing evidence that these gains in the copy number of $T$ are pathogenetically relevant, even in sporadic chordomas $(8,14,33)$ MUG-Chor1 shows a high amplification of brachyury and may therefore serve as an optimal in vitro model to further explore the function of brachyury in chordoma development.

Table III. Comparison of the MMP expression of low and high passages of MUG-Chor1 measured by Luminex technology.

\begin{tabular}{lllc}
\hline & Low passage & High passage & mRNA levels \\
\hline MMP-1 & $12410.44 \pm 2.95$ & $615.85 \pm 9.56$ & $0.157 \pm 0.08^{\mathrm{a}}$ \\
MMP-2 & $118469.71 \pm 10.98$ & $10026.24 \pm 6.84$ & $6.36 \mathrm{E}-0.5 \pm 1.02 \mathrm{E}-05^{\mathrm{b}}$ \\
MMP-3 & $8211.6 \pm 8.52$ & $825.26 \pm 5.21$ & - \\
MMP-9 & $1848.13 \pm 10$ & $188.10 \pm 2.83$ & -
\end{tabular}

MUG Chor 1 showed high MMP-1 and MMP-2 levels and low MMP-9 expression, which decreased by prolonged cultivation. mRNA expression determined by real-time PCR: The expression level was normalized $(\Delta \mathrm{Ct})$ to the expression of mRNA for $\beta$-actin, GAPD and hprt-n as the internal control and compared to the corresponding $\Delta \mathrm{Ct}(\Delta \Delta \mathrm{Ct})$ in controls. ${ }^{\mathrm{a}} \mathrm{p}=0.157 \pm 0.08(\mathrm{MMP}-1)$ and ${ }^{\mathrm{b}} \mathrm{p}=6.36 \mathrm{E}-0.5 \pm 1.02 \mathrm{E}-05$ (MMP-2), t-test, statistical significance, whereas the mRNA levels of MMP-3 and MMP-9 were too low to detect. 
Moreover, gains located on chromosomes 7 and 12 are also frequently observed in chordomas and are seen in the MUG-Chorl $(21,26,28,29)$. The most prominent candidates for chromosome 7 are CARD11, PMS2, ETV1, JAZF1, RALA, KZF, $E G F R, S B D S, C D K 6, M E T, S M O, K I A A, B R A F$ and for chromosome 12, KRAS and MDM2. Further functional studies on the MUG-Chorl are necessary, in order to better comprehend the potential impact of these genes on chordoma pathogenesis.

Conserved chromosomal losses during in vitro cultivation affect 6p22.3-p21.31,9p21.2-p21.3 and 10q25.2. Hallor et al recently demonstrated that $C D K N 2 A$ (P16 and P14) and $C D K N 2 B(P 15)$ loci in 9p21 were homo- or heterozygously lost in $70 \%$ of their investigated chordomas, indicating that inactivation of these genes constitutes a crucial step in chordoma development (5). The homozygous loss of this region in the parental tumor tissue (CN state 1) and the MUG-Chorl cell line (CN state 0 ) underlines the significance of this gene locus for this tumor entity and for chordoma cells during in vitro growth.

MUG-Chor1 demonstrates a loss at 10q15.3-q23.32 (includes PTEN locus). PTEN, a tumor suppressor gene, is commonly inactivated in malignant neoplasm by somatic mutations, deletions and or genetic inactivation. Heterogeneity in the expression of PTEN was recently described among chordomas (18) and the loss of PTEN has been associated with hyper-activation of mTORC1 signaling (18). PTEN has at least two major biochemical functions $(34,35)$ : a lipid phosphatase and protein phosphatase activity. The lipid phosphatase activity down-regulates AKT activity by negative regulation of the growth-factor-induced phosphatidylinositol-3 kinase (PI3K) pathway, and up-regulates proapoptotic mechanisms, such as caspases. The protein phosphatase activity of PTEN is involved in the inhibition of focal adhesion, in cell spreading and migration, as well as in the inhibition of growth-factorstimulated MAPK signaling. The combined effects of the PTEN lipid and protein phosphatase activities may result in aberrant cell growth and escape from apoptosis, as well as abnormal cell spreading and migration of neoplastic cells (35).

Recent immunohistochemical studies on chordomas have demonstrated potential therapeutic targets in the PI3K/ AKT/TSC1/TSC2/mTOR pathway and have explored the FGFR-RAS/RAF/MEK/ERK-ETS2/brachyury signaling pathways $(15,16)$. However, due to a lack of chordoma cell lines, functional studies were not performed.

Another region completely lost during in vitro cultivation affects 10q25. PDCD4 encoded within this region is considered a tumor suppressor that inhibits tumor promoter-induced neoplastic transformation by down-regulating JUN-dependent transcription (36). Another protein that is regulated by the expression of $P D C D 4$ is the urokinase receptor, which mediates degradation of extracellular matrix components and promotes tumor cell invasion and metastasis (37).

To explore further possible therapeutic targets, MMP expression in the MUG-Chor1 was evaluated. MMPs are secreted by a variety of cells, including fibroblasts (38). In recent years, tumor proteases, among other MMPs, have been shown to play a crucial role in tumor invasion in a variety of human neoplasms. Numerous studies have demonstrated that higher expressions of MMP-1, MMP-2 and MMP-9 in osteosarcomas or chondrosarcomas are indicative of invasiveness and progression in human bone tumors (39-44).
Immunohistochemical expression of MMP-1 and MMP-2 has been reported in chordomas and has been linked to infiltrative growth and poorer prognosis $(39,45)$. Based on the expression of MMP-1 and MMP-2 in the MUG-Chor1, this cell line is likely to serve as an in vitro model to investigate the effects of targeted therapies against MMPs (46).

A critical role in tumor development and progression is the interaction between cancer cells and the microenvironment. During the cultivation process of the chordoma cell line, fibroblasts were separated from tumor cells and cultured separately. These fibroblasts could be of potential use in studying tumorstroma interaction. Understanding the 'cross-talk' between tumor cells and their microenvironment may provide additional awareness into the mechanisms of tumorigenesis in chordomas.

In conclusion, in the present study we describe a highly characteristic, stable growing cell line, known as MUG-Chor1. MUG-Chor1 is markedly similar to chordomas in vivo and is likely, therefore, to serve as an optimal in vitro chordoma model. MUG-Chor1 could serve as a research tool to gain insight into the molecular mechanisms involved in the development and progression of this rare disease, and to explore novel treatments, which are urgently required.

\section{Acknowledgements}

The authors thank Professor Peter Möller and Dr Silke Brüderlein from the Institute of Pathology, University of Ulm, Germany, for their scientific support, as well as Mrs. Margit Gogg-Kamerer, Mrs. Elisabeth Gryger and the EuroBoNet consortium for their technical support. This study was supported by a grant from the National Bank of Austria [Jubiläumsfondsprojekt Nr. 13459].

\section{References}

1. Fletcher CDM, Unni KK and Mertens F (eds): Pathology and Genetics of Tumours of Soft Tissue and Bone. World Health Organization Classification of Tumours. Vol. 5. IARC Press, Lyon, 2002.

2. Chugh R, Tawbi H, Lucas DR, Biermann JS, Schuetze SM and Baker LH: Chordoma: The nonsarcoma primary bone tumor. Oncologist 12: 1344-1350, 2007.

3. Cummings BJ, Hodson DI and Bush RS: Chordoma: the results of megavoltage radiation therapy. Int J Radiat Oncol Biol Phys 9: 633-642, 1983.

4. Forsyth PA, Cascino TL, Shaw EG, Scheithauer BW, O'Fallon JR, Dozier JC and Piepgras DG: Intracranial chordomas: a clinicopathological and prognostic study of 51 cases. J Neurosurg 78: 741-747, 1993.

5. Hallor KH, Staaf J, Jonsson G, Heidenblad M, Vult von Steyern F, Bauer HC, Ijszenga M, Hogendoorn PC, Mandahl N, Szuhai K and Mertens F: Frequent deletion of the CDKN2A locus in chordoma: analysis of chromosomal imbalances using array comparative genomic hybridisation. Br J Cancer 98: 434-442, 2008.

6. Henderson SR, Guiliano D, Presneau N, McLean S, Frow R, Vujovic S, Anderson J, Sebire N, Whelan J, Athanasou N, Flanagan AM and Boshoff C: A molecular map of mesenchymal tumors. Genome Biol 6: R76, 2005.

7. Romeo S and Hogendoorn PC: Brachyury and chordoma: the chondroid-chordoid dilemma resolved? J Pathol 209: 143-146, 2006.

8. Vujovic S, Henderson S, Presneau N, Odell E, Jacques TS, Tirabosco R, Boshoff C, and Flanagan AM: Brachyury, a crucial regulator of notochordal development, is a novel biomarker for chordomas. J Pathol 209: 157-165, 2006.

9. Heikinheimo K, Persson S, Kindblom LG, Morgan PR and Virtanen I: Expression of different cytokeratin subclasses in human chordoma. J Pathol 164: 145-150, 1991. 
10. Coindre JM, Rivel J, Trojani M, De Mascarel I and De Mascarel A Immunohistological study in chordomas. J Pathol 150: 61-63, 1986.

11. Salisbury JR: Demonstration of cytokeratins and an epithelial membrane antigen in chondroid chordoma. J Pathol 153: 37-40, 1987.

12. Showell C, Binder O and Conlon FL: T-box genes in early embryogenesis. Dev Dyn 229: 201-218, 2004.

13. Tirabosco R, Mangham DC, Rosenberg AE, Vujovic S, Bousdras K, Pizzolitto S, De Maglio G, den Bakker MA, Di Francesco L, Kalil RK, Athanasou NA, O'Donnell P, et al: Brachyury expression in extra-axial skeletal and soft tissue chordomas: a marker that distinguishes chordoma from mixed tumor/myoepithelioma/parachordoma in soft tissue. Am J Surg Pathol 32: 572-580, 2008

14. Presneau N, Shalaby A, Ye H, Pillay N, Halai D, Idowu B, Tirabosco R, Whitwell D, Jacques TS, Kindblom LG Brüderlein S, Moller P, et al: Role of the transcription factor T (brachyury) in the pathogenesis of sporadic chordoma: a genetic and functional-based study. J Pathol 223: 327-335, 2011

15. Presneau N, Shalaby A, Idowu B, Gikas P, Cannon SR, Gout I, Diss T, Tirabosco R and Flanagan AM: Potential therapeutic targets for chordoma: PI3K/AKT/TSC1/TSC2/mTOR pathway. Br J Cancer 100: 1406-1414, 2009.

16. Shalaby AA, Presneau N, Idowu BD, Thompson L, Briggs TR, Tirabosco R, Diss TC and Flanagan AM: Analysis of the fibroblastic growth factor receptor-RAS/RAF/MEK/ERK-ETS2/ brachyury signalling pathway in chordomas. Mod Pathol 22: 996-1005, 2009

17. Shalaby A, Presneau N, Ye H, Halai D, Berisha F, Idowu B, Leithner A, Liegl B, Briggs TR, Bacsi K, Kindblom LG, Athanasou $\mathrm{N}$, et al: The role of epidermal growth factor receptor in chordoma pathogenesis: a potential therapeutic target. J Pathol 223: 336-346, 2011.

18. Han S, Polizzano C, Nielsen GP, Hornicek FJ, Rosenberg AE and Ramesh V: Aberrant hyperactivation of akt and Mammalian target of rapamycin complex 1 signaling in sporadic chordomas Clin Cancer Res 15: 1940-1946, 2009.

19. Sommer J, Itani DM, Homlar KC, Keedy VL, Halpern JL, Holt GE, Schwartz HS, Coffin CM, Kelley MJ and Cates JM: Methylthioadenosine phosphorylase and activated insulin-like growth factor-1 receptor/insulin receptor: potential therapeutic targets in chordoma. J Pathol 220: 608-617, 2010.

20. Bruderlein S, Sommer JB, Meltzer PS, Li S, Osada T, Ng D, Moller P, Alcorta DA and Kelley MJ. Molecular characterization of putative chordoma cell lines. Sarcoma 2010: 630129, 2010.

21. Scheil S, Bruderlein S, Liehr T, Starke H, Herms J, Schulte M and Moller P: Genome-wide analysis of sixteen chordomas by comparative genomic hybridization and cytogenetics of the first human chordoma cell line, U-CH1. Genes Chromosomes Cancer 32: 203-211, 2001.

22. Polinger IS: Separation of cell types in embryonic heart cell cultures. Exp Cell Res 63: 78-82, 1970.

23. Freshney RI: Culture of Animal Cells: A Manual of Basic Technique. 5th edition. Wiley-Liss, Hoboken, NJ, 2005.

24. Szuhai K, IJszenga M, Tanke HJ, Taminiau AH, de Schepper A van Duinen SG, Rosenberg C and Hogendoorn PC: Detection and molecular cytogenetic characterization of a novel ring chromosome in a histological variant of Ewing sarcoma. Cancer Genet Cytogenet 172: 12-22, 2007.

25. Szuhai K and Tanke HJ: COBRA: combined binary ratio labeling of nucleic-acid probes for multi-color fluorescence in situ hybridization karyotyping. Nat Protoc 1: 264-275, 2006.

26. Sawyer JR, Husain M and Al-Mefty O: Identification of isochromosome $1 \mathrm{q}$ as a recurring chromosome aberration in skull base chordomas: a new marker for aggressive tumors? Neurosurg Focus 10: E6, 2001.

27. Tallini G, Dorfman H, Brys P, Dal Cin P, De Wever I, Fletcher CD, Jonson K, Mandahl N, Mertens F, Mitelman F, Rosai J, Rydholm A, et al: Correlation between clinicopathological features and karyotype in 100 cartilaginous and chordoid tumours. A report from the Chromosomes and Morphology (CHAMP) Collaborative Study Group. J Pathol 196: 194-203, 2002.

28. Kuzniacka A, Mertens F, Strombeck B, Wiegant J and Mandahl N: Combined binary ratio labeling fluorescence in situ hybridization analysis of chordoma. Cancer Genet Cytogenet 151: $178-181,2004$
29. Brandal P, Bjerkehagen B, Danielsen $H$ and Heim S: Chromosome 7 abnormalities are common in chordomas. Cancer Genet Cytogenet 160: 15-21, 2005.

30. Yang XR, Beerman M, Bergen AW, Parry DM, Sheridan E, Liebsch NJ, Kelley MJ, Chanock S and Goldstein AM Corroboration of a familial chordoma locus on chromosome $7 \mathrm{q}$ and evidence of genetic heterogeneity using single nucleotide polymorphisms (SNPs). Int J Cancer 116: 487-491, 2005.

31. Miozzo M, Dalpra L, Riva P, Volonta M, Macciardi F, Pericotti S, Tibiletti MG, Cerati M, Rohde K, Larizza L and Fuhrman Conti AM: A tumor suppressor locus in familial and sporadic chordoma maps to 1p36. Int J Cancer 87: 68-72, 2000.

32. Riva P, Crosti F, Orzan F, Dalpra L, Mortini P, Parafioriti A, Pollo B, Fuhrman Conti AM, Miozzo M and Larizza L: Mapping of candidate region for chordoma development to $1 \mathrm{p} 36.13$ by LOH analysis. Int J Cancer 107: 493-497, 2003.

33. Yang XR, Ng D, Alcorta DA, Liebsch NJ, Sheridan E, Li S, Goldstein AM, Parry DM and Kelley MJ: T (brachyury) gene duplication confers major susceptibility to familial chordoma. Nat Genet 41: 1176-1178, 2009.

34. Stahl JM, Cheung M, Sharma A, Trivedi NR, Shanmugam S and Robertson GP: Loss of PTEN promotes tumor development in malignant melanoma. Cancer Res 63: 2881-2890, 2003.

35. Wu H, Goel V and Haluska FG: PTEN signaling pathways in melanoma. Oncogene 22: 3113-3122, 2003.

36. Lankat-Buttgereit B and Goke R: The tumour suppressor PDCD4: recent advances in the elucidation of function and regulation. Biol Cell 101: 309-317, 2009.

37. Leupold JH, Yang HS, Colburn NH, Asangani I, Post S and Allgayer H: Tumor suppressor PDCD4 inhibits invasion/intravasation and regulates urokinase receptor (u-PAR) gene expression via Sp-transcription factors. Oncogene 26: 4550-4562, 2007.

38. Fosang AJ, Last K, Knauper V, Neame PJ, Murphy G, Hardingham TE, Tschesche $\mathrm{H}$ and Hamilton JA: Fibroblast and neutrophil collagenases cleave at two sites in the cartilage aggrecan interglobular domain. Biochem J 295 (Pt 1): 273-276, 1993.

39. Naka T, Kuester D, Boltze C, Schulz TO, Samii A, Herold C, Ostertag $\mathrm{H}$ and Roessner A: Expression of matrix metalloproteinases-1, -2 , and -9; tissue inhibitors of matrix metalloproteinases- 1 and -2 ; cathepsin B; urokinase plasminogen activator; and plasminogen activator inhibitor, type I in skull base chordoma. Hum Pathol 39: 217-223, 2008

40. Foukas AF, Deshmukh NS, Grimer RJ, Mangham DC, Mangos EG, Taylor S: Stage-IIB osteosarcomas around the knee. A study of MMP-9 in surviving tumour cells. J Bone Joint Surg Br 84: 706-711, 2002.

41. Uchibori M, Nishida Y, Nagasaka T, Yamada Y, Nakanishi K and Ishiguro $\mathrm{N}$ : Increased expression of membrane-type matrix metalloproteinase-1 is correlated with poor prognosis in patients with osteosarcoma. Int J Oncol 28: 33-42, 2006.

42. Hackel C, Czerniak B, Ayala AG, Radig K and Roessner A Expression of plasminogen activators and plasminogen activator inhibitor 1 in dedifferentiated chondrosarcoma. Cancer 79: 53-58, 1997.

43. Hackel CG, Krueger S, Grote HJ, Oshiro Y, Hodges S, Johnston DA, Johnson ME, Roessner A, Ayala AG and Czerniak B: Overexpression of cathepsin B and urokinase plasminogen activator is associated with increased risk of recurrence and metastasis in patients with chondrosarcoma. Cancer 89 995-1003, 2000.

44. Kawashima A, Okada Y, Nakanishi I, Ueda Y, Iwata K and Roessner A: Immunolocalization of matrix metalloproteinases and tissue inhibitors of metalloproteinases in human chondrosarcomas. Gen Diagn Pathol 142: 129-137, 1997.

45 Naka T, Boltze C, Samii A, Samii M, Herold C, Ostertag H, Iwamoto Y, Oda Y, Tsuneyoshi M, Kuester D and Roessner A: Expression of c-MET, low-molecular-weight cytokeratin, matrix metalloproteinases-1 and -2 in spinal chordoma. Histopathology 54: 607-613, 2009.

46. Overall $\mathrm{CM}$ and Kleifeld $\mathrm{O}$ : Tumour microenvironment opinion: validating matrix metalloproteinases as drug targets and anti-targets for cancer therapy. Nat Rev Cancer 6: 227-239, 2006. 